\title{
OPINI MAHASISWA PROGRAM STUDI PENDIDIKAN SENI RUPA TERHADAP PELAKSANAAN KKN PPL TERPADU UNIVERSITAS NEGERI MAKASSAR ANGKATAN XV TAHUN 2017
}

\author{
Rizki Fitria \\ Prodi pendidikan Seni Rupa Fakultas Seni dan Desain Universitas Negeri Makassar \\ rizkifitriah160297@gmail.com
}

\begin{abstract}
ABSTRAK
Permasalahan utama penelitian ini adalah opini mahasiswa Program Studi Pendidikan Seni Rupa Fakultas Seni dan Desain tentang pelaksanaan KKN-PPL Terpadu Universitas Negeri Makassar angatan XV tahun 2017. Penelitian ini merupakan penelitian survei yang bertujuan untuk mengamati pelaksanaan KKN-PPL Terpadu. Variabel dalam penelitian ini adalah opini mahasiswa Program Studi Pendidikan Seni Rupa Fakultas Seni dan Desain tentang pelaksanaan KKN-PPL Terpadu Universitas Negeri Makassar terhadap: (1) pelaksanaan pembimbingan mahasiswa KKN-PPL Terpadu oleh guru pamong dan dosen pembimbing lapangan; (2) Pelaksanaan pengelolaan KKN-PPL Terpadu oleh panitia pelaksanaan; (3) Permasalah yang dihadapi mahasiswa peserta KKN-PPL Terpadu. Populasi dan sampel dalam penelitian ini mahasiswa Program Studi Pendidikan Seni Rupa Fakultas Seni dan Desain Universitas Negeri Makassar yang telah mengikuti KKN-PPL Terpadu pada semester ganjil tahun 2017 yang berjumlah 49 Orang. Sampel yang digunakan berjumlah 30 orang. Teknik pengumpulan data adalah angket dan wawancara, data tersebut diolah dan disajikan melalui tabel persentase. Teknik analisis data yang digunakan adalah deskriptif kuantitatif dan deskriptif kualitatif. Hasil penelitian menunjukan bahwa; (1) opini mahasiswa Program Studi Pendidikan Seni Rupa Fakultas Seni tentang pelaksanaan pembimbingan memperlihatkan hasil yang bervariasi, yakni sebanyak 73,34\% responden menyatakan sudah efektif dan 26,66\% menyatakan tidak efektif; (2) opini mahasiswa Program Studi Pendidikan Seni Rupa Fakultas Seni dan Desain manajemen pengelolaan sebanyak $73,34 \%$ responden menyatakan sudah baik, dan 26,66\% responden menyatakan tidak baik, sebanyak dari segi layanan pelaksanaan sebanyak $66,67 \%$ responden manyatakan sudah baik, dan 33,33\% responden menyatakan tidak baik. Data hasil wawancara terhadap, (3) opini mahasiswa Program Studi Pendidikan Seni Rupa tentang permasalahan yang dihadapi selama pelaksanaan KKN-PPL Universitas Negeri Makassar tahun 2017, meliputi: rendahnya partisipasi masyarakat, dukungan pihak sekolah dan siswa, masalah akademik, masalah pondokan dan masalah keterbatasan dana.
\end{abstract}

Kata Kunci: Opini mahasiswa, pelaksanaan, KKN-PPL Terpadu.

\section{PENDAHULUAN}

Kegiatan KKN-PPL Terpadu merupakan sintesis dari pengalaman penyelenggaraan PPL dan KKN yang selama ini diselenggarakan Universitas Negeri Makassar (UNM). Dengan pemaduan tersebut diharapkan dapat memberikan pengalaman belajar bagi mahasiswa, terutama dalam hal pengalaman pembelajaran, memperluas wawasan, melatih dan mengembang-kan kompetensi yang diperlukan dalam bidangnya, meningkatkan keterampilan, kemandirian, tanggung jawab, dan kemampuan dalam memecahkan masalahmasalah pendidikan (Mulyadi, dkk., 2015: 1).
Penyelenggaraan Mata kuliah KKN dan PPL secara terpadu juga mengacu pada Undang-Undang Nomor 14 Tahun 2005 tentang Guru dan Dosen, yakni empat kompetensi guru, yakni kompetensi pedagogik, kompetensi kepribadian, kompetensi profesional, dan kompetensi sosial.Tuntutan peningkatan penyelenggaraan program KKN-PPL Terpadu mengandung konsekuensi pada pengelolaan dan manajemen yang profesional, sehingga dapat diciptakan sistem yang efektif dan efisien. Sistem yang efektif adalah sistem yang dapat mencapai tujuan kurikuler dari kedua matakuliah tersebut secara tepat. Sistem yang efisien adalah sistem 
yang dapat mendukung pencapaian tujuan secara tepat waktu, atau bahkan lebih cepat. Kedua sistem tersebut diharapkan dapat memperpendek rata-rata lama penyelesaian studi mahasiswa Universitas Negeri Makassar, yang pada saat ini masih berkisar 4,5 tahun. (Mulyadi, dkk., 2015: 2)

Dalam buku petunjuk teknik pelaksanaan KKN-PPL Terpadu Universitas Negeri Makassar dijelaskan bahwa dalam penyelenggaraan program KKN-PPLTerpadu, ada tiga prinsip yang dipakai sebagai dasar dalam pengembangan program KKN-PPL Terpadu, yaitu:

1.) Keterpaduan $\mathrm{KKN}$ dan PPL tidak berarti memadukan visi dan misi tiap-tiap program karena setiap matakuliah ini mempunyai visi dan misi yang berbeda. Keterpaduan KKN dan PPL pada dasarnya merupakan keterpaduan manajemen dan waktu. Keterpaduan pengelolaan mencakup pengelolaan program maupun pelaksanaannya,

2.) Beban mahasiswa yang mengikuti program KKN -PPL Terpadu setara dengan keterpaduan bobot sks dari kedua mata kuliah tersebut, dan

3.) Kegiatan KKN-PPL Terpadu ini dilaksanakan pada komunitas sekolah/madrasah dan masyarakat. (Mulyadi, dkk., 2015: 2)

KKN-PPL terpadu muncul dari konsep atas upaya melatih calon guru agar tidak canggung dan mampu berintegrasi dalam mewujudkan proses belajar mengajar yang efektif yang berlandaskan Kurikulum Sekolah sesuai dengan amanah pendidikan nasional, atas kesadaran mahasiswa sebagai calon sarjana untuk dapat memanfaatkan sebagian waktu belajarnya menyumbangkan pengetahuan dan ilmu yang telah diperolehnya secara langsung dalam membantu memecahkan dan melaksanakan pembangunan di dalam kehidupan masyarakat dan Sekolah.

KKN-PPL Terpadu merupakan keterpaduan dari dua matakuliah, yakni Keduanya merupakan matakuliah wajib dalam struktur kurikulum S1 kependidikan. KKNPPL Terpadu merupakan dua matakuliah, yaitu PPL dan KKN, yang kegiatannya dilaksanakan secara terpadu, namun penilaian dilaksanakan secara terpisah. Adapun Lokasi yang akan dijadikan tempat KKN-PPL terpadu adalah sekolah/madrasah dan masyarakat lingkungan sekolah/madrasah yang ada di masing-masing lokasi tugas peserta KKN PPL Terpadu. Sekolah/madrasah yang menjadi lokasi meliputi PAUD, TK, SD, MI,SMP, MTs, SMA, SMK, dan MA, serta lingkungan masyarakat di sekitarnya. Sekolah atau madrasah yang digunakan sebagai lokasi KKN PPL Terpadu dipilih berdasarkan pertimbangan bahwa sekolah tersebut layak untuk melaksanakan program KKN dan PPL secara terpadu (Mulyadi, dkk., 2015: 8).

Ada beberapa keluhan dikalangan mahasiswa tentang masalah-masalah yang dihadapi dalam proses pelaksanaan KKN-PPL Terpadu menjadi terganggu, baik masalah sosial maupun budaya, bahkan latar belakang budaya dan nilai-nilai yang dimiliki mahasiswa yang berbeda-beda setiap individu dan kelompok memicu terjadinya permasalahan yang menghambat berlangsungnya pelaksanaan kegiatan.

Dari uraian di atas peneliti tertarik untuk melakukan penelitian terkait dengan Program KKN-PPL Terpadu Universitas Negeri Makassar pada angkatan XV tahun 2017, sebagai bahan evaluasi dan acuan terhadap pelaksanaan KKN-PPL Terpadu Universitas Negeri Makassar pada masa-masa yang akan datang. Adapun manfaat dalam penelitian ini adalah (1) Sebagai bahan masukan bagi pihak pengelola dalam mengambil kebijakan terkait dengan upaya perbaikan pengelolaan dan pelaksanaan program KKN-PPLTerpadu dimasa-masa yang akan datang, (2) Sebagai bahan masukan bagi institusi guna mencari solusi pemecahan masalah pengelolaan dan pelaksanaan program KKN-PPL Terpadu Universitas Negeri Makassar, (3) Memberikan sumbangan pemikiran dan informasi dalam upaya peningkatan mutu dan kualitas dalam pelaksanaan KKN-PPL Terpadu.

\section{METODE PENELITIAN}

Adapun jenis penelitian yang digunakan dalam penelitian ini adalah jenis penelitian survei. Dimana menurut Kerngiler (1996) seperti yang dikutip oleh Ridwan pada tahun 2006, "penelitian survei adalah peneitian yang dilakukan pada populasi besar maupun kecil, tetapi data yang dipelajari adalah data dari sample yang diambil dari populasi tersebut, 
sehingga ditemukan kejadian-kejadian relatif, distribusi, dan hubungan antar variabel sosiologis maupun psikologis".

Menurut Suharsimi Arikunto (1988: 99) variabel penelitian ini adalah objek penelitian atau apa yang menjadi titik perhatian suatu penelitian. Sesuai dengan permasalah penelitian, maka yang akan menjadi variabel dalam penelitian adalah opini mahasiswa.

Mahasiswa Program Studi Pendidikan

Seni Rupa Fakultas Seni dan Desain yang memprogramkan matakuliah KKN-PPL Terpadu Universitas Negeri Makassar pada tahun 2017 angkatan XV semester ganji yang berjumlah 49 orang.

Tidak semua populasi dapat diperoleh pada saat penelitian ini, maka penelitian ini menggambarkan sampel aksidental yakni peserta KKN-PPL Terpadu yang dapat penulis temui yang berjumlah 30 orang.

Angket atau kuesioner merupakan data yang dilakukan dengan cara memberi seperangkat pertanyaan atau pernyataan tertulis kepada responden untuk dijawabnya. Kuesioner merupakan teknik pengumpulan data yang efisien bila peneliti tahu pasti tentang variabel yang akan diukur dan tahu apa yang bisa diharapkan dari responden. Data dan informasi yang diperlukan dalam dalam penelitian ini dijaring melalui angket. Angket dimaksudkan untuk mengumpulkan data yang ada di lapangan sesuai dengan apa yang dirasakan oleh mahasiswa peserta KKN-PPL Terpadu.

Wawancara yaitu pengumpulan data dengan cara mengajukan pertanyaan secara

lisan yang telah disusun oleh peneliti ke responden yang menjadi sampel penelitian.Wawancara bertujuan untuk mengumpulkan keterangan yang objektif, relevan dengan yang dialami mahasiswa, dimana data yang terkait dengan permasalahan yang dihadapi mahasiswa dalam pelaksanaan program KKN-PPL Terpadu.

Analisis data merupakan proses penyusunan data yang diperoleh agar dapat ditafsirkan, Lalu diinterpretasikan kemudian disusun secara sistematis, sehingga memberikan gambaran yang bermakna tentang masalah yang sedang diteliti. Setelah data-data terkumpul, selanjutnya dilakukan analisis data, dalam hal ini teknik analisis data yang digunakan adalah teknik analisis deskriptif- kuantitatif metode ini digunakan untuk mengkaji variabel yang ada pada penelitian. Untuk memudahkan dalam melakukan analisis data yang telah diperoleh dari responden, data tersebut ditabulasikan sesuai dengan jawaban responden pada angket kedalam tabel, kemudian dihitung presentasinya, dan selanjutnya dianalisis. perhitungan dilakukan dengan menggunakan rumus yang dikemukakan oleh Kountur (2005, hlm.16) sebagai berikut:

$$
P=\frac{f}{n} \times 100 \%
$$

\section{Keterangan \\ $P$ : Presentase jawaban \\ F : Jumlah jawaban yang diperoleh \\ $\mathrm{n}$ : Jumlah responden}

Untuk menafsirkan besarnya presentasi yang diperoleh dari hasil data, didalam penelitian ini digunakan penafsiran dengan kriteria sebagai berikut:

Tabel. 1 presentase kriteria penilaian

\begin{tabular}{|c|c|}
\hline Persentase & Klasifikasi \\
\hline $91-100 \%$ & (sangat efektif) \\
$81-90 \%$ & (efektif) \\
$71-80 \%$ & (cukup efektif) \\
$61-70 \%$ & (kurang efektif) \\
$<60 \%$ & (tidak efektif) \\
\hline
\end{tabular}

Sedangkan data yang bersifat deskriptifkualitatif dianalisis melalui teknik analisis deskriptif-kualitatif setelah diinterpretasi terlebih dahulu terhadap data berupa komentar atau saran responden. Dengan demikian data yang dikumpul akan menggambarkan secara mendetail tentang Opini Mahasiswa Program Studi Pendidikan Seni Rupa terhadap Pelaksanaan KKN-PPL Terpadu Universitas Negeri Makassar Angkatan XV Tahun 2017.

Teknik analisis data yang digunakan dalam penelitian deskriptif-kualitatif ini dikemukakan oleh Miles dan Huberman, Aktivitas dalam menganalisis data kualitatif yaitu:

\section{Reduksi Data (Data Reduction)}

Mereduksi data berarti merangkum, memilih hal-hal yang pokok,memfokuskan pada hal-hal yang penting, dicari tema dan 
polanya. Dengan demikian data yang telah direduksi akan memberikan gambaran yang lebih jelas dan mempermudah peneliti untuk melakukan pengumpulan data selanjutnya dan mencarinya bila diperlukan.

2. Penyajian Data (Data Display)

Menyajikan data yaitu penyusunan sekumpulan informasi yang memberi kemungkinan adanya penarikan kesimpulan dan penarikan tindakan. Dalam penelitian kualitatif, penyajian data bisa dilakukan dalam bentuk uraian singkat, bagan, hubungan antar kategori, flowchart atau sejenisnya. Dalam penelitian ini, secara teknis data-data akan disajikan dalam bentuk teks.

3. Penarikan Kesimpulan (Conclusion Drawing)

Langkah ketiga dalam analisis data menurut Miles dan Huberman adalah penarikan kesimpulan dan verifikasi. Kesimpulan dalam penelitian kualitatif adalah merupakan temuan baru yang sebelumnya belum pernah ada. Dengan demikian kesimpulan dalam penelitian kualitatif mungkin dapat menjawab rumusan masalah yang dirumuskan sejak awal, tetapi mungkin juga tidak karena masalah dan rumusan masalah dalam penelitian kualitatif masih bersifat sementara dan akan berkembang setelah penelitian.

\section{HASIL DAN PEMBAHASAN}

\subsection{Hasil}

Dalam bagian ini disajikan hasil penelitian yang dikumpulkan melalui angket dan wawancara.

\subsubsection{Opini mahasiswa tentang pelaksanaan pembimbingan $\mathrm{KKN}$ - PPL Terpadu.}

Opini mahasiswa Program Studi Pendidikan Seni Rupa Fakultas Seni dan Desain tentang pelaksanaan pembimbingan KKN-PPL Terpadu Universitas Negeri Makassar tahun 2017 ialah pembimbingan oleh guru pamong dan dosen pembimbing lapangan.
Tabel 2. Opini mahasiswa tentang pelaksanaan Pembimbingan Guru Pamong

\begin{tabular}{|c|c|c|}
\hline \multirow{2}{*}{ Alternatif jawaban } & \multicolumn{2}{|c|}{ Responden } \\
\cline { 2 - 3 } & Frekuensi & $\begin{array}{c}\text { Persentase } \\
(\%)\end{array}$ \\
\hline $\begin{array}{c}\text { 91-100\% } \\
\text { (sangat efektif) } \\
\begin{array}{c}81-90 \% \\
\text { (efektif) }\end{array}\end{array}$ & 7 & 33,34 \\
$\begin{array}{c}71-80 \% \\
\text { (cukup efektif) } \\
\text { 61-70\% } \\
\text { (kurang efektif) } \\
<60 \%\end{array}$ & 5 & 16,67 \\
(tidak efektif) & 6 & 6,66 \\
\hline Jumlah & 30 & 100 \\
\hline
\end{tabular}

Sumber Data: diolah dari angket nomor 1.

Data pada tabel 2 di atas memperlihatkan bahwa opini mahasiswa tentang pelaksanaan pembimbingan yang dilakukan oleh guru pamong, yakni: sebanyak 7 responden $(23,34 \%)$ menyatakan sangat efektif, 10 responden $(33,33 \%)$ menyatakan efektif, 5 responden $(16,67 \%)$ menyatakan cukup efektif, 2 responden $(6,66 \%)$ menyatakan kurang efektif, dan 6 responden (20\%) menyatakan tidak efektif.

Tabel 3. Opini mahasiswa tentang pelaksanaan pembimbingan Dosen Pembimbingan Lapangan

\begin{tabular}{|c|c|c|}
\hline \multirow{2}{*}{ Alternatif jawaban } & \multicolumn{2}{|c|}{ Responden } \\
\cline { 2 - 3 } & Frekuensi & $\begin{array}{c}\text { Persentase } \\
(\%)\end{array}$ \\
\hline $\begin{array}{c}91-100 \% \\
\text { (sangat efektif) } \\
\begin{array}{c}81-90 \% \\
\text { (efektif) }\end{array}\end{array}$ & 13 & 43,34 \\
$\begin{array}{c}71-80 \% \\
\text { (cukup efektif) } \\
\text { 61-70\% } \\
\text { (kurang efektif) } \\
<60 \%\end{array}$ & 0 & 0 \\
(tidak efektif) & 4 & 13,34 \\
\hline Jumlah & 30 & 100 \\
\hline
\end{tabular}

Sumber Data: diolah dari angket nomor 2.

Data pada tabel 3 di atas memperlihatkan opini mahasiswa tentang pelaksanaan pembimbingan dari pihak dosen pembimbing lapangan, yakni: sebanyak 13 responden $(43,34 \%)$ menyatakan sangat efektif, 9 
responden $(30 \%)$ menyatakan efektif, tidak ada responden yang mengatakan cukup efektif, 4 responden $(13,34 \%)$ menyatakan kurang efektif, dan 4 responden $(13,34 \%)$ menyatakan tidak efektif.

\subsubsection{Opini mahasiswa tentang kualitas pengelolaan KKN-PPL Terpadu}

Opini mahasiswa Program Studi Pendidikan Seni Rupa Fakultas Seni dan Desain tentang kualitas pengelolaan KKN-PPL Terpadu Universitas Negeri Makassar tahun 2017. Kualitas pengelolaan KKN-PPL Terpadu yang dimaksud ialah mutu kualitas penyelenggaraan kegiatan ditinjau dari aspek manajemen pengelolaan dan layanan pelaksanaan sehingga program kegiatan terlaksana sesuai dengan rencana tanpa mengalami kendala yang berarti (tercapainya tujuan yang diharapkan).

Tabel 4. Opini mahasiswa tentang kualitas manajemen pengelolaan

\begin{tabular}{|c|c|c|}
\hline \multirow{2}{*}{$\begin{array}{c}\text { Alternatif } \\
\text { jawaban }\end{array}$} & \multicolumn{2}{|c|}{ Responden } \\
\cline { 2 - 3 } $\begin{array}{c}\text { 91-100\% } \\
\text { (sangat baik) }\end{array}$ & 2 & 6,66 \\
$\begin{array}{c}81-90 \% \\
\text { (baik) }\end{array}$ & 8 & 26,67 \\
$\begin{array}{c}71-80 \% \\
\text { (cukup baik) } \\
61-70 \%\end{array}$ & 12 & 40 \\
$\begin{array}{c}\text { (kurang baik) } \\
<60 \%\end{array}$ & 5 & 16,67 \\
(tidak baik) & 3 & 10 \\
\hline Jumlah & 30 & 100 \\
\hline
\end{tabular}

Sumber Data: diolah dari angket nomor

Data pada tabel 4 di atas memperlihatkan kualitas manajemen pengelolaan, yakni: sebanyak 2 responden $(6,66 \%)$ menyatakan sangat baik, 8 responden $(26,67 \%)$ yang menyatakan baik, 12 responden $(40 \%)$ menyatakan cukup baik, 5 responden $(16,67 \%)$ menyatakan kurang baik, 3 responden $(10 \%)$ menyatakan tidak baik.
Tabel 5. Opini mahasiswa tentang kualitas layanan pelaksanaan

\begin{tabular}{|c|c|c|}
\hline \multirow{2}{*}{$\begin{array}{c}\text { Alternatif } \\
\text { jawaban }\end{array}$} & \multicolumn{2}{|c|}{ Responden } \\
\cline { 2 - 3 } $\begin{array}{c}\text { F1-100\% } \\
\text { (sangat baik) }\end{array}$ & 0 & $\begin{array}{c}\text { Persentase } \\
(\%)\end{array}$ \\
$\begin{array}{c}81-90 \% \text { (baik) } \\
71-80 \% \text { (cukup } \\
\text { baik) }\end{array}$ & 12 & 0 \\
$\begin{array}{c}\text { 61-70\% (kurang } \\
\text { baik) } \\
<60 \%\end{array}$ & 8 & 26,67 \\
(tidak baik) & 2 & 26,67 \\
\hline Jumlah & 30 & 6,66 \\
\hline
\end{tabular}

Sumber Data: diolah dari angket nomor 4.

Data pada tabel 5 di atas memperlihatkan kualitas layanan pelaksanaan KKN-PPL Terpadu, yakni: tidak ada responden yang menyatakan sangat baik, sebanyak 12 responden $(40 \%)$ yang menyatakan baik, 8 responden $(26,66 \%)$ mengatakan cukup baik, 8 responden $(26,66 \%)$ menyatakan kurang baik, dan 2 responden $(6,66 \%)$ menyatakan tidak baik.

\subsubsection{Opini mahasiswa tentang permasalahan selama KKN-PPL Terpadu}

Permasalahan yang dimaksudkan di sini ialah permasalahan yang menjadi keterbatasan atau kendala yang dirasakan oleh mahasiswa peserta KKN-PPL Terpadu.

Tabel 6 Opini mahasiswa tentang permasalahan selama KKN-PPL Terpadu

\begin{tabular}{|l|l|l|}
\hline No & $\begin{array}{l}\text { Jenis } \\
\text { permasalah }\end{array}$ & \multicolumn{1}{c|}{$\begin{array}{c}\text { Deskripsi } \\
\text { permasalahan }\end{array}$} \\
\hline 1. & $\begin{array}{l}\text { Partisipasi/du } \\
\text { kungan } \\
\text { masyarakat }\end{array}$ & $\begin{array}{l}\text { Rendahnya partisipasi } \\
\text { masyarakat, baik } \\
\text { dalam hal keterlibatan } \\
\text { pada kegiatan program } \\
\text { kerja mahasiswa } \\
\text { maupun dalam hal } \\
\text { bantuan dana untuk } \\
\text { mendukung } \\
\text { pelaksanaan program } \\
\text { kerja di masyarakat. }\end{array}$ \\
\hline 2. & $\begin{array}{l}\text { Partisipasi/du } \\
\text { kungan pihak }\end{array}$ & \begin{tabular}{l} 
1) $\begin{array}{l}\text { Beberapa sekolah } \\
\text { tidak menyiapkan } \\
\text { dana una rantuk }\end{array}$ \\
\hline
\end{tabular} \\
\hline
\end{tabular}




\begin{tabular}{|c|c|c|}
\hline & $\begin{array}{l}\text { sekolah dan } \\
\text { siswa }\end{array}$ & $\begin{array}{l}\text { mendukung } \\
\text { pelaksanaan } \\
\text { program kerja } \\
\text { mahasiswa. } \\
\text { 2) Kurangnya } \\
\text { patisipasi siswa } \\
\text { dalam pelaksanaan } \\
\text { program kerja. } \\
\text { 3) Siswa-siswa yang } \\
\text { kurang susah diatur. }\end{array}$ \\
\hline 3. & $\begin{array}{l}\text { Masalah } \\
\text { akademik }\end{array}$ & $\begin{array}{l}\text { Pada umumnya } \\
\text { sekolah di daerah tidak } \\
\text { memiliki fasilitas } \\
\text { pembelajaran yang } \\
\text { memadai, seperti } \\
\text { bahan/media } \\
\text { pengajaran, namun hal } \\
\text { tersebut tidak } \\
\text { menjadikan masalah } \\
\text { yang berarti sebab hal } \\
\text { tersebut dapat disiasati } \\
\text { oleh mahasiswa } \\
\text { dengan cara } \\
\text { mengadakan } \\
\text { bahan/media } \\
\text { pengajaran jauh-jauh } \\
\text { hari dengan } \\
\text { menggunakan printer } \\
\text { milik sekolah. }\end{array}$ \\
\hline 4. & $\begin{array}{l}\text { Masalah } \\
\text { pondokan }\end{array}$ & $\begin{array}{l}\text { 1.) Beberapa } \\
\text { pondokan } \\
\text { mahasiswa relatif } \\
\text { jauh dari sekolah } \\
\text { tempat ber-PPL, } \\
\text { dan terkadang } \\
\text { tidak terjangkau } \\
\text { dengan angkutan } \\
\text { kota sehingga } \\
\text { terkadang } \\
\text { mahasiswa harus } \\
\text { berjalan kaki ke } \\
\text { sekolah } \\
\text { menempuh jarak } \\
\text { kurang lebih 1 km. } \\
\text { Akhirnya pindah } \\
\text { pondokan, bahkan } \\
\text { ada yang pindah } \\
\text { pondok sampai } \\
\text { tiga kali. } \\
\text { 2.) Lingkungan di } \\
\text { sekitar pondokan } \\
\text { yang kurang aman. } \\
\text { 3.) Salah satu } \\
\text { pondokan } \\
\text { mahasiswa } \\
\text { dianggap kurang } \\
\text { nyaman tinggal } \\
\text { bersama pemilik }\end{array}$ \\
\hline
\end{tabular}

\begin{tabular}{|c|c|c|c|}
\hline & & & $\begin{array}{l}\text { rumah sehingga } \\
\text { mahasiswa } \\
\text { berinisiatif pindah, } \\
\text { bahkan pindah } \\
\text { pondokan sampai } 2 \\
\text { kali karena merasa } \\
\text { tidak familiar } \\
\text { dengan pemilik } \\
\text { rumah. }\end{array}$ \\
\hline 5. & $\begin{array}{l}\text { Masalah } \\
\text { keterbatasan } \\
\text { dana/biaya }\end{array}$ & 1.) & $\begin{array}{l}\text { Pada umunya } \\
\text { mahasiswa } \\
\text { kekurangan dana } \\
\text { untuk pembiayaan } \\
\text { program kerja di } \\
\text { sekolah karena } \\
\text { tidak semua } \\
\text { sekolah } \\
\text { menyiapkan dana } \\
\text { untuk program } \\
\text { kerja mahasiswa di } \\
\text { sekolah. } \\
\text { Ada juga sekolah } \\
\text { yang lambat } \\
\text { mencairkan dana } \\
\text { sehingga program } \\
\text { kerja tidak } \\
\text { terlaksana. }\end{array}$ \\
\hline
\end{tabular}

Sumber Data: diolah dari format wawancara

Berdasarkan data pada tabel 6 di atas dapat dijelaskan bahwa permasalahan tersebut sebagai berikut:

1. Masalah partisipasi masyarakat. Partisipasi masyarakat sangat rendah, baik dalam keterlibatan pada pelaksanaan program kerja mahasiswa maupun dalam hal bantuan dana untuk mendukung pelaksanaan program kerja dimasyarakat. Menurut pengakuan dari beberapa mahasiswa bahwa masyarakat setempat acuh dengan keberadaan mahasiswa/kurang berpartisipasi

2. Partisipasi/dukungan pihak sekolah dan siswa. Beberapa sekolah tidak menyiapkan dana untuk mendukung pelaksanaan program kerja mahasiswa. Partisipasi siswa dalam pelaksanaan program kerja kurang berpartisispasi. Siswa-siswa yang kurang susah diatur.

3. Masalah akademik. Pada umumnya sekolah di daerah-daerah kurang memiliki fasilitas yang memadai untuk menunjang suatu pembelajaran. seperti bahan/media pengajaran, namun hal tersebut tidak menjadikan masalah yang berarti sebab hal tersebut dapat disiasati oleh mahasiswa dengan cara mengadakan 
bahan/media pengajaran jauh-jauh hari dengan menggunakan printer milik sekolah. Rendahnya partisipasi siswa dalam pelaksanaan program kerja di sekolah.

4. Masalah pondokan. Beberapa pondokan mahasiswa relatif jauh dari sekolah tempat ber-PPL, dan terkadang tidak terjangkau dengan angkot sehingga terkadang mahasiswa harus berjalan kaki ke sekolah menempuh jarak kurang lebih $1 \mathrm{~km}$. Akhirnya pindah pondokan, bahkan ada yang pindah pondok sampai tiga kali. Kasus lain adalah lingkungan di sekitar pondokan yang kurang aman yang mengakibatkan mahasiswa di pondokan tersebut kehilangan beberapa barang berharga miliknya. Salah satu pondokan mahasiswa dianggap kurang nyaman tinggal bersama pemilik rumah sehingga mahasiswa berinisiatif pindah, bahkan pindah pondokan sampai 2 kali karena merasa tidak familiar dengan pemilik rumah.

5. Masalah biaya keterbatasan dana. Pada umunya mahasiswa merasa kekurangan dana untuk pembiayaan program kerja di sekolah karena tidak semua sekolah menyiapkan dana untuk program kerja mahasiswa di sekolah sehingga untuk mengatasi masalah yang ada mahasiswa terpaksa secara bersama-sama menanggung biaya program kerja tersebut.

\subsection{Pembahasan}

Pada bagian ini penulis menguraikan hasil penelitian yang telah diperoleh di lapangan dengan mengaitkan teori-teori yang telah dikemukakan terdahulu dengan kenyataan yang didapat di lapangan.

Pembahasan tentang opini mahasiswa Seni Rupa terhadap pelaksanaan KKN PPL Terpadu Universitas Negeri Makassar tahun 2017.

\subsubsection{Opini mahasiswa tentang pelaksanaan pembimbingan $\mathrm{KKN}$ - PPL Terpadu}

Pelaksanaan pembimbingan KKNPPL Terpadu yang dimaksud dalam pembahasan ini meliputi pembimbingan oleh guru pamong dan dosen pembimbing lapangan. Adapun tugas dan tanggung jawab guru pamong dan dosen pembimbing lapangan adalah: (1) Mengadakan diskusi antara kepala sekolah, dosen pembimbing lapangan, guru pamong dan mahasiswa secara terjadwal minimal 3 kali selama kegiatan KKN-PPL Terpadu berlangsung; (2) Pembimbingan yang dilakukan oleh dosen pembimbing lapangan secara kolektif di lokasi KKN-PPL Terpadu; (3) Bersama guru pamong menilai kinerja praktikan dalam bentuk ujian praktik dan membuat rekapitulasi nilai akhir KKN-PPL Terpadu; (4) Bersama guru pamong memperbaiki dan meningkatkan kinerja praktikan.

Hasil survei yang menggambarkan pelaksanaan pembimbingan yang dilakukan oleh guru pamong memperlihatkan hasil yang bervariasi, yakni: sebanyak 23,34\% responden menyatakan sangat efektif, 33,33\% responden menyatakan efektif, sebanyak 16,67\% responden menyatakan cukup efektif, sebanyak $6,66 \%$ responden menyatakan kurang efektif dan sebanyak $20 \%$ responden menyatakan tidak efektif.

Opini mahasiswa tentang pelaksanaan pembimbingan yang dilakukan oleh guru pamong dinilai sudah efektif dengan alasan bahwa guru pamong sudah melakukan tugas sebagaimana mestinya, yakni: membimbing mahasiswa sejak perencanaan dan implementasi sampai kepada evaluasi, memberikan pembimbingan pada saat mahasiswa melaksanakan observasi di kelas. Namun disisi lain masih ada 26,66\% responden yang menyatakan bahwa pelaksanaan pembimbingan yang dilakukan oleh guru pamong kurang efektif dengan alasan bahwa masih ada diantaranya yang belum melaksanakan tugasnya sebagaimana mestinya.

Sedangkan pelaksanaan pembimbingan yang dilakukan oleh dosen pembimbing lapangan menunjukan hasil yang bervariasi pula, yakni: sebanyak $43,34 \%$ responden yang menyatakan sangat efektif, sebanyak $30 \%$ responden menyatakan efektif, sedangkan $13,34 \%$ responden yang menyatakan kurang efektif dan tidak efektif.

Opini mahasiswa tentang pelaksanaan pembimbingan yang dilakukan oleh dosen pembimbing lapangan dinilai efektif dengan alasan bahwa dosen pembimbing lapangan sudah melaksanakan tugas sebagaimana mestinya, yaitu: membimbing mahasiswa untuk melaksanakan tugasnya sesuai dengan Buku Petunjuk KKN-PPL Terpadu, 
membimbing mahasiswa sejak perencanaan dan evaluasi di lokasi, menyelenggarakan diskusi antar kepala sekolah dan guru pamong, menilai kinerja mahasiswa, menyerahkan dan menarik kembali mahasiswa dari lapangan. Namun disisi lain, masih ada 26,66\% responden yang menyatakan kurang efektif dengan alasan bahwa masih ada diantara dosen pembimbing lapangan yang tidak melaksanakan tugas sebagaimana mestinya. Bahkan terdapat beberapa sekolah yang tidak pernah dikunjungi oleh dosen pembimbing lapangan.

\subsubsection{Opini mahasiswa tentang kualitas pengelolaan KKN-PPL Terpadu}

Pengelolaan merupakan suatu yang meliputi perencanaan, pengorganisasian, pergerakan, pengawasan, yang setiap bidang yang mempergunakan ilmu pengetahuanya untuk mencapai tujuan yang telah ditetapkan. Dalam suatu pengelolaan kegiatan KKN-PPL terpadu terdapat prinsip-prinsip yang harus diperhatikan seperti; (a) terbimbing, artinya mahasiswa praktikan dalam melaksanakan tugas-tugasnya yang dibimbing oleh Dosen Pembimbing, Guru Pamong dan Kepala Sekolah; (b) terkonsentrasi, artinya mahasiswa praktikan harus betul-betul fokus hanya pada kegiatan KKN-PPL Terpasdu saja. Jadi mereka harus betul-betul totalitas mengikuti kegiatan di sekolah baik pembelajaran maupun administrasi/manejerial. Maka mahasiswa praktikan tidak diperkenankan mengambil matakuliah kecuali skripsi; (c) terpadu, artinya seluruh kegiatan KKN-PPL Terpadu merupakan satu kesatuan; (d) terarah, artinya semua kegiatan dan tugas-tugas mahasiswa dalam pelaksanaan kegiatan KKN-PPL Terpadu diarahkan untuk mencapai tujuan dan sasaran KKN-PPL Terpadu.

Terkait dengan masalah kualitas manajemen pengelolaan menunjukan hasil yang bervariasi, yakni: sebanyak 6,66\% responden yang menyatakan sangat baik, $26,67 \%$ responden yang menyatakan baik, $40 \%$ responden menyatakan cukup baik, $16,67 \%$ responden yang menyatakan kurang baik, dan $(10 \%)$ responden menyatakan tidak baik.

Opini mahasiswa tentang kualitas pengelolaan yang dilakukan jika dilihat dari aspek manajemen pengelolaan dinilai baik dengan alasan bahwa mahasiswa terbimbing dalam melaksanakan tugas-tugasnya, terkonsentrasi artinya mahasiswa harus fokus pada pelaksanaan KKN-PPL Terpadu dan tidak diperkenankan untuk mengambil matakuliah kecuali skripsi, terpadu artinya kegiatan KKN-PPL Terpadu menjadi satu kesatuan, terarah artinya semua tugas mahasiswa diarahkan untuk mencapai tujuan dan sasaran KKN-PPL Terpadu, mengatur serta mengawasi mahasiswa dan membaginya kedalam kelompok-kelompok tertentu yang terdiri dari berbagai prodi. Sementara disisi lain masih ada $26,66 \%$ responden yang menyatakan kurang baik dengan alasan bahwa panitia pengelolaan belum melaksanakan tugas sebagaimana mestinya.

Hasil survei yang dilakukan oleh peneliti untuk menggambarkan seberapa baik kualitas layanan pelaksanaan yang dilakukan oleh pihak kampus selama kegiatan KKN-PPL Terpadu. Kualitas layanan pelaksanaan dapat diartikan sebagai upaya meningkatkan kebutuhan dalam pelayanan yang dilakukan demi terwujudnya tujuan yang diharapkan baik dari pihak kampus maupun mahasiswa, Demi terlaksananya tujuan dalam memperlancar kegiatan KKN-PPL Terpadu. Layanan yang dimaksud seperti; layanan pada saat pengumpulan berkas sebagai persyaratan dalam mengikuti kegiatan KKN-PPL Terpadu dan pelayanan pada saat pengumpulan laporan hasil kegiatan KKN-PPL Terpadu.

Kualitas layanan pelaksanaan menunjukan hasil yang bervariasi pula, yakni: sebanyak $40 \%$ responden yang menyatakan baik, sebanyak $26,67 \%$ responden menyatakan cukup baik dan kurang baik, $6,66 \%$ responden menyatakan tidak baik.

Opini mahasiswa tentang kualitas pengelolaan yang dilakukan jika dilihat dari aspek kualitas layanan pelaksanaan dinilai sudah baik dengan alasan bahwa layanan yang dilakukan oleh panitia pelaksanaan sudah baik jika dilihat dari pelayanan pada saat pengumpulan berkas dan pelayanan pada saat pengumpulan laporan KKN-PPL Terpadu. Sementara disisi lain masih ada 33,33\% responden yang menyatakan kurang baik dengan alasan bahwa panitia pengelolaan belum melaksanakan tugas sebagaimana mestinya. 


\subsubsection{Opini mahasiswa tentang permasalahan yang dialami selama KKN-PPL Terpadu}

Dalam rangkaian pelaksanaan KKN-PPL Terpadu Universitas Negeri Makassar terdapat beberapa masalah, seperti: partisipasi/dukungan masyarakat yang kurang baik dalam hal keteribatan pada kegiatan program kerja mahasiswa baik dalam hal bantuan moril maupun materi untuk mendukung terlaksananya program kerja dimasyarakat, bahkan masyarakat setempat acuh terhadap keberadaan mahasiswa. Masalah akademik yang meliputi fasilitas sekolah yang kurang lengkap dan tidak memadai, seperti media pembelajaran namun hal tersebut tidak menjadi masalah yang berarti bagi mahasiswa sebab berbagai bahan yang ada di lingkungan sekolah dapat dijadikan sebagai media pembelajaran. Adapun masalah pondokan yang menjadi masalah bagi mahasiswa, yaitu jauhnya pondokan dengan sekolah sehingga mahasiswa kesulitan dalam menempuh jarak yang begitu jauh, lingkungan sekitar pondok yang tidak aman membuat barang-barang berharga dicuri. Masalah lain yang muncul selama kegiatan KKN-PPL Terpadu berlangsung adalah masalah keterbatasan biaya sehingga program kerja yang direncanakan menjadi terhambat karena tidak semua sekolah menyiapkan dana untuk pembiayaan program kerja yang diadakan oleh mahasiswa.

\section{SIMPULAN DAN SARAN}

Berdasarkan hasil analisis data dan pembahasan tentang opini mahasiswa Program Studi Pendidikan Seni Rupa terhadap pelaksanaan KKN-PPL Terpadu Universitas Negeri Makassar angkatan XV tahun 2017, maka dapat ditarik kesimpulan sebagai berikut:

1. Opini mahasiwa Program Studi Pendidikan Seni Rupa Fakultas Seni dan Desain tentang pelaksanaan pembimbingan KKN-PPL Terpadu Universitas Negeri Makassar tahun 2017 yang dilakukan oleh guru pamong dan dosen pembimbing lapangan, memperlihatkan hasil yang barvariasi, yakni sebanyak $73,34 \%$ responden menyatakan sudah efektif dan 26,66\% responden menyatakan tidak efektif.
2. Opini mahasiswa Program Studi Pendidikan Seni Rupa Fakultas Seni dan Desain tentang kualitas pengelolaan KKN-PPL Terpadu Universitas Negeri Makassar tahun 2017 menunjukan hasil yang bervariasi pula, yaitu: sebanyak $73,34 \%$ responden menyatakan bahwa kualitas manajemen pengelolaan sudah baik dan 26,66\% responden menyatakan tidak baik. Sedangkan kualitas layanan pelaksanaan, yakni sebanyak $66,67 \%$ responden menyatakan sudah baik dan $33,33 \%$ responden menyatakan tidak baik.

3. Opini mahasiswa tentang permasalahan yang dihadapi selama pelaksanaan KKNPPL Terpadu Universitas Negeri Makassar tahun 2017, adalah: rendahnya partisipasi masyarakat, kurangnya dukungan dari pihak sekolah untuk biaya program kerja, fasilitas sekolah yang tidak memadai, jauhnya pondokan dari sekolah dan terkadang tidak terjangkau dengan angkutan kota, sekolah yang lambat mencairkan dana.

\section{DAFTAR PUSTAKA}

Mulyadi, Dkk. 2015. Petunjuk Teknis Pelaksanaan KKN-PPL Terpadu Universitas Negeri Makassar. Makassar: Badan Penerbit UNM.

Oktri permata lani. 2010. Skripsi: Opini Mahasiswa terhadap pelaksanaan Kuliah Kerja Nyata (kukerja) di Universitas Riau. Riau: Universitas Negeri Makassar.

Prof. Dr. Sugiyono. 2016. Metode Penelitian Pendidikan (Pendekatan Kuantitatif, Kualitatif, dan $R \& D$. Bandung: alfabeta.

Yabu M dan Paisal. 2017. Efektivitas Pelaksanaan Program KKN-PPL Terpadu: Studi terhadap Opini Mahasiswa Peserta KKNPPL Terpadu Universitas Negeri Makassar. Makassar: Universitas Negeri Makassar.

Online.(http://infodanpengertian.bpogspot.co.id 16/02/pengertian-opini-menurut-paraahli.html?m=1). Diakses 11 Maret 2018.

Online.(https://www.kata.co.id/Pengertian/Opini/1 019). Diakses 11 Maret 2018. 
Rizki Fitria, OPINI MAHASISWA PROGRAM STUDI PENDIDIKAN SENI RUPA TERHADAP PELAKSANAAN KKN PPL TERPADU UNIVERSITAS NEGERI MAKASSAR ANGKATAN XV TAHUN 2017

Online.(http://www.situsbelajronline.com/bahasaindonesia/fakta-dan-opini-pengertianmacam-ciri-dan-contohnya.html). Diakses 16 April 2018

Online.(http://pengertianisp.blogspot.co.id/2015/04/pengertianopini-dan-jenis-jenisnya.html). Diakses 16 April 2018.

Online.(https://www.scribd.com/document/358755 347/Bab-III-Skripsi-Isma). Diakses 06 maret 2018.

Online.(http://www.sumberpengertian.co/pengertia n-variabel-penelitian). Diakses 30 juni 2018.

Online.(http://tiranurindah.blogspot.com/2012/03/ makalah-metode-penelitiansurvai.html?m=). Diakses 30 juni 2018. 